\title{
Kesehatan Tenggorok pada Siswa Sekolah Dasar Inpres Kema 3 Kabupaten Minahasa Utara
}

\author{
${ }^{1}$ Pricilia G. L. Likuayang \\ ${ }^{2}$ Olivia C. P. Pelealu \\ ${ }^{2}$ Steward K. Mengko
}

\author{
${ }^{1}$ Program Studi Pendidikan Dokter Fakultas Kedokteran Universitas Sam Ratulangi Manado \\ ${ }^{2}$ Bagian/SMF Telinga Hidung Tenggorok-Bedah Kepala Leher Fakultas Kedokteran \\ Universitas Sam Ratulangi Manado \\ Email: Pricilia.Likuayang12057@yahoo.com
}

\begin{abstract}
Tonsillitis is the inflammation of tonsil caused by bacteria, viruses, as well as infectious and non-infectious causes. Exposure of dust and air polution, some types of food, poor oral hygne, weather, and physical exhaustion become the predisposing factors of chronic tonsillitis. Long summer increases the number of dust particles which trigger the occurence of infection. This study was aimed to obtain the throat health status of students of SD Inpres Kema 3 (elementary school students) who lived in coastal areas. This was a descriptive prospective study by examining the students' throats (size, surface, as well as tonsil and pharynx color). Subjects were 24 students of $6^{\text {th }}$ grade at SD Inpres Kema 3. The results showed that most of the subjects had pathological tonsil size. Moreover, some of them had granule hypertrophy. Conclusion: The throat health status of the students at SD Inpres Kema 3 was categorized as unfavorable.
\end{abstract}

Key words: throat health status

\begin{abstract}
Abstrak: Tonsilitis adalah radang tonsil yang disebabkan oleh bakteri, viru, dan penyebab infeksi maupun non-infeksi lainnya. Paparan debu dan polusi udara, beberapa jenis makanan, kebersihan mulut yang buruk, serta pengaruh cuaca dan kelelahan fisik menjadi faktor predisposisi dari tonsilitis kronik. Musim kemarau panjang yang mengakibatkan bertambahnya partikel debu di udara memicu terjadinya infeksi. Penelitian ini bertujuan untuk mengetahui gambaran kesehatan tenggorok pada siswa SD Inpres Kema 3 yang tinggal di daerah pesisir pantai. Jenis penelitian ialah deskriptif prospektif dengan melihat gambaran tenggorok dari segi ukuran, permukaan dan warna tonsil serta faring. Subjek penelitian ialah siswa kelas VI SD Inpres Kema 3 yang berjumlah 24 orang. Hasil penelitian menunjukkan bahwa pada pemeriksaan ditemukan sebagian besar subyek penelitian memiliki ukuran tonsil yang patologik dan beberapa diantaranya memiliki granula hipertrofi. Simpulan: Kesehatan tenggorok siswa SD Inpres Kema 3 tergolong kurang baik.
\end{abstract}

Kata kunci: kesehatan tenggorok

Tenggorok merupakan tempat masuknya makanan ke kerongkongan dan udara ke paru-paru. Letak tenggorok (faring) bermula dari dasar tengkorak sampai persambungannya dengan esofagus pada ketinggian tulang rawan (kartilago) krikoid. ${ }^{1}$

Faring terbagi atas tiga bagian, yaitu nasofaring, orofaring, dan laringofaring (hipofaring). Faring mempunyai beberapa unsur yaitu mukosa, palut lendir (mucous blanket), dan otot. ${ }^{2}$

Tonsil adalah massa jaringan limfoid yang terletak di bagian belakang mulut pada kedua sudut orofaring dan merupakan salah satu struktur yang penting bagi sistem pertahanan tubuh terutama pada protein 
asing yang dimakan atau dihirup. Cincin Waldeyer merupakan pertahanan terhadap infeksi, terdiri atas susunan organ limfoid yang terdapat dalam rongga mulut yaitu tonsil faringeal (adenoid), tonsil palatina (tonsil fausial), tonsil lingual (tosil pangkal lidah), tonsil tuba Eustachius (lateral band dinding faring/Gerlach's tonsil). ${ }^{3,4}$ Tonsilitis adalah peradangan tonsil palatina yang disebabkan oleh bakteri, virus, dan penyebab infeksi maupun non-infeksi lainnya. ${ }^{5-8}$

Paparan debu dan polusi udara, beberapa jenis makanan, kebiasaan mencuci tangan, kebersihan mulut yang buruk, pengaruh cuaca dan kelelahan fisik menjadi faktor predisposisi dari tonsilitis kronik. Kondisi lingkungan yang kurang bersih merupakan salah satu komponen penting bagi penularan penyakit. Banyak penyakit menular yang berkembang karena kesulitan mendapatkan air bersih dan drainase tidak memadai, sanitasi yang buruk serta pembuangan limbah padat tidak pada tempatnya. Polusi udara merupakan masalah global, terutama bagi kesehatan masyarakat yang hidup di perkotaan. Peningkatan level polusi partikulat sangat berpengaruh meningkatkan mortalitas, penyakit jantung dan infeksi pada saluran pernapasan.

Infeksi saluran pernapasan akut (ISPA) di Indonesia masih merupakan penyebab tersering morbiditas dan mortalitas pada anak. Pada tahun 1996/1997 temuan penderita ISPA pada anak berkisar antara 30\%$40 \%$. Tonsilitis kronis pada anak dapat disebabkan karena anak sering menderita ISPA atau tonsilitis akut yang tidak diterapi adekuat. Berdasarkan data epidemiologi penyakit THT-KL pada 7 provinsi di Indonesia pada tahun 1994-1996, prevalensi tonsilitis kronik tertinggi setelah nasofaringitis akut $(4,6 \%)$ yaitu sebesar $3,8 \%{ }^{9}$

Penyakit tonsilitis merupakan permasalahan yang umum ditemukan pada anak. Penderita tonsil merupakan pasien yang sering datang di praktek dokter ahli bagian telinga hidung tenggorok-kepala dan leher (THT-KL), dokter anak, maupun tempat pelayanan kesehatan lainnya. ${ }^{3,10}$ Tonsilitis juga merupakan salah satu penyebab ketidakhadiran anak di sekolah. ${ }^{5,11}$
Di Indonesia, pemerataan pendidikan telah dilakukan hingga mencapai daerah terpencil walaupun dari segi fasilitas berbeda dengan yang ada di perkotaan. Perhatian dan didikan orang tua terhadap anak untuk hidup bersih dipengaruhi oleh tingkat pengetahuan dan kesadaran akan kebiasaan hidup sehat yang masih minim. Penelitian ini bertujuan untuk mengetahui gambaran kesehatan tenggorok para siswa di SD Inpres Kema 3 di Kabupaten Minahasa Utara.

\section{METODE PENELITIAN}

Jenis penelitian ini ialah deskriptif observasional dengan subjek penelitian 24 orang siswa SD kelas VI berusia 11-13 tahun. Penelitian ini berlangsung pada tanggal 13 Oktober 2015 di SD INPRES Kema 3 Kabupaten Minahasa Utara. Variabel penelitian ialah ukuran tonsil, permukaan tonsil, warna tonsil, warna faring, dan gambaran faring.

\section{HASIL PENELITIAN}

Tabel 1 memperlihatkan distribusi gambaran ukuran tonsil subyek penelitian. Sebagian besar subyek memperlihatkan ukuran tonsil T1/T1 atau T2/T2.

Tabel 1. Distribusi gambaran ukuran tonsil siswa SD Inpres Kema 3

\begin{tabular}{ccccc}
\hline \multicolumn{5}{c}{ Ukuran tonsil } \\
\hline $\mathrm{T} 1 / \mathrm{T} 1$ & $\mathrm{~T} 2 / \mathrm{T} 2$ & $\mathrm{~T} 3 / \mathrm{T} 3$ & $\mathrm{~T} 4 / \mathrm{T} 4$ & Jumlah \\
10 & 12 & 2 & 0 & 24 \\
\hline
\end{tabular}

Tabel 2 memperlihatkan distribusi gambaran permukaan tonsil subyek penelitian. Sebagian besar subyek memiliki permukaan tonsil yang normal.

Tabel 2. Distribusi gambaran permukaan tonsil siswa SD Inpres Kema 3

\begin{tabular}{cccc}
\hline \multicolumn{4}{c}{ Permukaan tonsil } \\
\hline Normal & Kasar & Kripta lebar & Detritus \\
21 & 3 & 5 & 0 \\
\hline
\end{tabular}

Tabel 3 memperlihatkan distribusi gambaran warna tonsil subyek penelitian. Sebagian besar memiliki warna tonsil normal. 
Tabel 3. Distribusi gambaran warna tonsil siswa SD Inpres Kema 3

\begin{tabular}{cc}
\hline \multicolumn{2}{c}{ Warna tonsil } \\
\hline Normal & Hiperemis \\
23 & 1 \\
\hline
\end{tabular}

Tabel 4 memperlihatkan distribusi warna faring subyek penelitian. Sebagian besar subyek penelitian memiliki warna faring yang normal.

Tabel 4. Distribusi warna faring siswa SD Inpres Kema 3

\begin{tabular}{cc}
\hline \multicolumn{2}{c}{ Warna faring } \\
\hline Normal & Hiperemis \\
24 & 0 \\
\hline
\end{tabular}

Tabel 5 memperlihatkan distribusi gambaran warna faring subyek penelitian. Pada sebagian besar subyek penelitian tidak tampak adanya granula hipertrofi.

Tabel 5. Distribusi gambaran faring siswa SD Inpres Kema 3

\begin{tabular}{cc}
\hline \multicolumn{2}{c}{ Gambaran faring } \\
\hline Granula hipertrofi & Granula hipertrofi \\
$(-)$ & $(+)$ \\
20 & 4 \\
\hline
\end{tabular}

\section{BAHASAN}

Hasil survei kesehatan tenggorok di SD Inpres Kema 3 menunjukkan pada umumnya para siswa memiliki kesehatan tenggorok yang baik. Dari pemeriksaan tenggorok yang dilakukan sebagian besar siswa memiliki hasil pemeriksaan yang normal. Pada penelitian mengenai ukuran tonsil dengan total jumlah sampel 24 orang siswa, didapatkan sebanyak 10 siswa $(41,67 \%)$ memiliki tonsil yang normal dan sebanyak 14 siswa $(58,33 \%)$ memiliki ukuran tonsil yang patologik; 10 siswa $(41,67 \%)$ memiliki ukuran tonsil T1; 12 siswa $(50 \%)$ memiliki ukuran tonsil $\mathrm{T} 2$; dan 2 siswa $(8,33 \%)$ lainnya memiliki ukuran tonsil T3. Tidak didapatkan ukuran tonsil T0 dan T4 pada subyek penelitian. Berdasarkan hasil tersebut, didapatkan jumlah subyek penelitian yang memiliki ukuran tonsil patologik lebih banyak daripada yang memiliki ukuran normal. Tonsil yang patologik ini dikarenakan anak -anak mungkin cenderung memiliki pola makan yang buruk karena kurangnya pengetahuan anak tentang pola makan yang baik. $^{12}$

Hasil penelitian mengenai permukaan tonsil mendapatkan dari 24 siswa, sebanyak 21 siswa $(87,5 \%)$ memiliki permukaan tonsil yang normal dan sebanyak 3 siswa $(12,5 \%)$ memiliki permukaan tonsil yang kasar. Terdapat 5 siswa $(20,83 \%)$ dengan kripta yang melebar. Dari hasil penelitian ini, didapatkan jumlah siswa yang memiliki permukaan tonsil normal lebih banyak daripada yang memiliki permukaan kasar dan kripta melebar. Kripta melebar menunjukkan proses radang berulang. Hal tersebut menyebabkan epitel mukosa dan jarringan limfoid terkikis, sehingga pada proses penyembuhan jaringan limfoid diganti oleh jaringan parut yang akan mengalami pengerutan. ${ }^{13}$

Hasil penelitian mengenai warna tonsil mendapatkan sebanyak 23 siswa $(95,83 \%)$ memiliki warna tonsil yang normal dan 1 siswa $(4,16 \%)$ memiliki warna tonsil yang hiperemik. Dari hasil tersebut, didapatkan bahwa jumlah siswa yang memiliki warna tonsil normal lebih banyak daripada yang memiliki warna tonsil hiperemik. Warna tonsil yang hiperemik menunjukkan adanya peradangan pada tonsil. ${ }^{14}$

Hasil penelitian mengenai warna faring memperlihatkan sebanyak 24 siswa $(100 \%)$ memiliki warna faring yang normal.

Berdasarkan hasil penelitian mengenai gambaran faring didapatkan sebanyak 20 siswa $(83,33 \%)$ memiliki granula yang tidak hipertrofi; 4 siswa $(16,67 \%)$ memiliki granula yang hipertrofi. Pada pemeriksaan dengan granula yang hipertrofi menunjukkan tanda faringitis kronik.

Hasil penelitian yang dilakukan pada musim kemarau panjang didapatkan bahwa paparan debu dan polusi udara, kebersihan mulut yang buruk, pengaruh cuaca panas dan kelelahan fisik menjadi faktor predisposisi dari tonsilitis kronik yang selaras dengan penelitian sebelumnya oleh Lanteloma. ${ }^{15}$ Penelitian ini juga mendu- 
kung pernyataan bahwa penyakit tonsilitis merupakan permasalahan yang umum ditemukan pada anak. ${ }^{3}$

Peneliti menyadari bahwa hasil penelitian ini masih kurang akurat karena jumlah subyek penelitian dalam populasi masih kurang sehingga belum dapat dijadikan tolak ukur untuk gambaran kesehatan tenggorok secara umum. Masalah kesehatan tenggorok tidak hanya dilihat dari tingkat paparan polusi maupun tingkat kebersihan makanan tetapi juga kebiasaan hidup tidak bersih karena pengetahuan umum setiap individu masyarakat yang masih kurang merupakan salah satu faktor pencetus terkenanya penyakit tenggorok.

\section{SIMPULAN}

Berdasarkan hasil penelitian ini dapat disimpulkan bahwa kesehatan tenggorok dari sebagian besar siswa SD Inpres Kema 3 tergolong kurang baik.

\section{SARAN}

Disarankan agar dilakukan penyuluhan untuk edukasi kepada orang tua dan siswa tentang pentingnya pola hidup bersih dan sehat agar terhindar dari berbagai macam penyakit.

\section{DAFTAR PUSTAKA}

1. Lubis FH. Gambaran gejala gangguan pernapasan pada nelayan Panah Hijau Lingkungan 8 Kecamatan Medan Marelan tahun 2010. 2010. [cited 2014 Sept 22]. Available from: http:// repository.usu.ac.id/bitstream/1234567 89/21820/4/Chapter\%20II.pdf

2. Fan OH. Karakteristik penderita faringitis akut di RSUP H. Adam Malik Medan Tahun 2011-2012. 2014. [cited 2014 Sept 22]. Available from: http://repository. usu.ac.id/bitstream/123456789/40128/4 /ChapterII.pdf

3. Brodsky L, Poje Ch. Tonsillitis, tonsilec-tomy and adenoidectomy. In: Bailey BJ, Johnson JT, Newlands SD editors. Ototlaryngology Head and Neck Surgery Vol 1 (4th ed). Philadelphia: Lippincott Williams \& Wilkins, 2006; p. 1183-98.

4. Siregar FPJ. Prevalensi tonsilitis akut pada siswa yang absen di SMA Negeri 4 Medan bulan Juli 2011 - Juli 2012. Medan: Universitas Sumatera Utara; 2012.

5. Mohan S, Dharamraj K, Dindial R, Mathur D, Parmasad V, Ramdhanie J, et al. Physician behaviour for antimicrobial prescribing for paediatric upper respiratory tract infections: a survey in general practice in Trinidad, West Indies. Annals Clin Microbiol Antimicrob. 2004;3(11):1-8.

6. Brook I. The role of anaerobic bacteria in tonsillitis. Int $\mathbf{J}$ Pediatr Otorhinolaryngol. 2005;69:9-19.

7. Kornblut AD. Non-neoplastic diseases of the tonsils and adenoids. In: Paparella MM, Shumrick DA, Gluckman JL, Meyerhoff WL, editors.Otolaryngology (3th ed). Philadelphia WB Saunders Company, 1991; p. 2129-46.

8. Hammouda M, Khalek ZA, Awad S, Azis MA, Fathy M. Chronic tonsillitis bacteriology in Egyptian children including antimicrobial susceptibility. Aust J Basic \& Appl Sci. 2009;3(3): 1948-53.

9. Farokah, Suprihati, Suyitno S. Hubungan tonsilitis kronik dengan prestasi belajar pada siswa kelas II Sekolah Dasar di Kota Semarang. Cermin Dunia Kedokteran. 2007;155:87-91.

10. Bista M, Sinha BK, Amatya RCM, Tuladhar NR, Pokharel BM. Comparison of core and surface cultures in recurrent tonsillitis. Journal of institute of medicine 2005;27:6-65.

11. Tom LWC, Jacobs DR. Deseases of the oral cavity, oropharynx, and nasopharynxn. In: Snow JB, Ballenger JJ editors. Ballenger's Otorhinolaryngology Head and Neck Surgery (16th ed). Hamilton Ontario: Bc Decker, 2003; p. 1020-47.

12. Arsyad FW, Wahyuni S, Ipa A. Hubungan antara pengetahuan dan pola makan dengan tonsilitis pada anak usia Sekolah Dasar di wilayah kerja Puskesmas Minasate Kab. Pangkep. ISJD. 2013;2(1):20-6.

13. Amalia N. Karakteristik penderita tonsilitis kronik di RSUP H. Adam Malik Medan Tahun 2009. 2009. [cited 2014 Sept 23]. Available from: http:// repository.usu.ac.id/bitstream/1234567 89/27640/4/Chapter\%20II.pdf 
Likuayang, Pelalu, Mengko: Kesehatan tenggorok pada siswa Sekolah Dasar ...

14. Herawati S, Rukmini S. Ilmu Penyakit Telinga Hidung Tenggorok. Jakarta: EGC, 2003; p. 568.

15. Lanteloma R. Survei kesehatan tenggorok pada siswa Sekolah Menengah
Kejuruan 2 Kota Manado dan siswa Sekolah Menengah Kejuruan 1 Desa Tumpaan [Skripsi]. Manado: Universitas Sam Ratulangi; 2013. 